\title{
Weakness of investment in Portugal: what role do credit supply and fiscal consolidation shocks play?
}

\section{Laurent Maurin ${ }^{1}$ id}

Received: 21 August 2017 / Accepted: 29 November 2018/ Published online: 11 January 2019

(C) ISEG - Instituto Superior de Economia e Gestão 2019

\begin{abstract}
In order to illustrate how tightened financial conditions have hampered investment in Portugal, we estimate a Factor Augmented Vector AutoRegressive model (FAVAR) with Bayesian techniques. We extract a financial conditions indicator and identify credit supply, demand and fiscal consolidation shocks with sign restrictions. We show that changes in financial conditions, which result from both credit supply shocks and fiscal shocks, have a protracted impact, especially on bank loans and bank lending spreads. We then develop a scenario in which we the tightening in financial conditions in the wake of the sovereign crisis is attributed to credit supply shocks. The analysis suggests that, due to the crisis, by the end of 2017, Portuguese GDP, corporate investment and corporate loans were reduced by respectively 6, 22 and 20 p.p., public investment by 1 p.p. of GDP and bank lending spreads widened by 80 b.p.
\end{abstract}

Keywords Corporate investment ' Public investment ' Financial indicators · Activity ' Cost of financing ' Bank loans ' FAVAR model ' Bayesian estimation ' Sign restrictions ' Scenario analysis ' Sovereign stress ' Demand shock · Credit shock · Fiscal consolidation

JEL Classification C32 $\cdot$ C11 $\cdot$ E22 $\cdot$ E60 $\cdot$ G21

The author thanks, without implicating, Antonio Afonso, Michael G. Arghyrou, and Ricardo Santos, as well as the participants of the 6th UECE Conference on Economic and financial Adjustments, in Lisbon, and two anonymous referees. The views expressed in this paper are solely those of the author and do not necessarily reflect the views of the EIB.

Laurent Maurin

1.maurin@eib.org

1 Secretariat General, Economics Department, European Investment Bank, 98-100 boulevard Konrad Adenauer, Kirchberg, L-2950 Luxembourg 